\title{
Disclosure Quality and its Impact on Financial Reporting Quality, Audit Quality, and Investors' Perceptions of the Quality of Financial Reporting: A Literature Review
}

\author{
Dr Yousef Alwardat ${ }^{1}$ \\ ${ }^{1}$ Assistant Professor in Accounting, King Abdulaziz University, Saudi Arabia \\ Correspondence: Dr Yousef Alwardat, Assistant Professor in Accounting, King Abdulaziz University, Saudi Arabia
}

Received: June 1, 2019

Accepted: June 26, 2019

Online Published: August 24, 2019

doi:10.5430/afr.v8n3p201

URL: https://doi.org/10.5430/afr.v8n3p201

\begin{abstract}
The purpose of this paper is to review the most recent empirical studies on corporate disclosures, in the aim of examining the link between disclosure quality (DQ) and financial reporting quality, audit quality, and investors' perceptions of the quality of financial reporting and providing recommendations for future research on this topic. Seventy-eight empirical studies, published in several relevant journals from 2003 onwards (i.e. one year after the commencement of the SOX 2002), have been categorized and analyzed in order to identify the link between the aforementioned variables. The analysis has revealed that the Sarbanes Oxley Act (2002) has significantly increased management awareness of the importance of accounting disclosures. In general, the majority of the studies which have been reviewed have identified the presence of a positive correlation between four aforementioned variables. These findings lend credence to the belief that these variables may well be classified as dependent since they are complementary. Finally, the review presents a discussion of the limitations of the studies and provides useful recommendations for future research on this topic.
\end{abstract}

Keywords: disclosure quality, financial reporting quality, audit quality, quality measures, investors' perceptions

Paper type: Literature review.

\section{Introduction}

Due to an increase in the complexity of regulations, business contexts, firm strategies, and operations, narrative explanations have become a fundamental accompaniment to financial statements (Beretta and Bozzolan, 2008). This has made corporate disclosure one of the most important attributes of financial reporting in public companies, as it helps to achieve the goal of communicating financial and non-financial information to decision makers (Akman, 2011). It is also an effective mechanism for resolving information asymmetries and improving investors and stakeholders' trust in corporate financial reports (Chandra et al., 2006). Major corporate scandals involving Enron, WorldCom, and Parmalat have shown that new compliance standards for publicly held corporations are sorely needed (Andrikopoulos \& Kriklani, 2013). Further, questions regarding the agency conflict between managers and shareholders re-emerged following the 2007 global financial crisis (Chandra et al., 2006).

In response to these financial scandals, several regulations have been implemented. The broad aim of these regulations is to cut down on these incidences of corporate fraud and to enact a comprehensive reform of business financial practices in order to improve the transparency and disclosure in financial reporting. This is important, as transparency is seen to play a vital role in solving information asymmetries and their resulting agency issues (Bischof \& Daske, 2013).

One of these regulations was the Sarbanes Oxley Act (SOX), which was put in place in 2002. The act is an American federal law that enacted a comprehensive reform of business financial practices. It is aimed at publicly held corporations, their internal financial controls, and their financial reporting audit procedures as performed by external auditing firms. Another aim of the act is to protect investors by improving the accuracy and reliability of corporate disclosures in financial statements. Accordingly, the act has amended several Security Exchange acts (SEC. 401 to 409) which have a list of disclosure mandatory requirements (see www.sec.gov/about/laws/secrulesregs.htm).

For example, several sections of the SOX are aimed at increasing the obligations of chief executive officers (CEOs) and chief financial officers (CFOs) in order to make them more responsible for financial statements. 
Such sections include Section 302, which states that CEOs and CFOs must certify financial statements in every annual or quarterly report. CEOs and CFOs are also responsible for reviewing reports in order to ensure that they include all necessary information and that they do not include any false statements of material facts, thereby ensuring the transparency of statements. Further, it is mandatory that CEOs and CFOs ensure that the financial statements and reports present information in an unbiased and objective manner (Kiattikulwattana, 2014). Hence, the SOX regulations include a mandatory list of disclosure requirements to be implemented by publicly held companies in the aim of enhancing the quality of financial reporting.

Financial reporting quality is an important attribute of financial reports. Investors' confidence in the credibility of these reports and whether they present the truth about the performance of publicly held companies will influence their perceptions and direct their investment decisions. Audit quality is another important issue, since auditors play an intermediary role between investors and the board of directors.

Despite the high volume of research which has been conducted on corporate disclosures, the SOX regulations have placed strong emphasis on this issue and have made it one of the hottest research topics worldwide for the past two decades. Therefore, the objective of this current study is to survey the published research related to corporate disclosures. The aim is to contribute to the body of research by illustrating in more depth the impact of corporate disclosure quality on the quality of financial reporting, audit quality, and investors' perceptions of the quality of financial reporting. Further, the study reaches novel conclusions from the current literature and presents a thorough discussion on possible future research.

The review is arranged as follows: the following section presents the theoretical framework of the study, section three presents the methodology, and section four presents a discussion of the impact of DQ on reporting quality, audit quality, and investors' perceptions. Finally, section five presents the conclusion and recommendations for future research.

\section{Theoretical Framework}

There are several principal theories which explain and argue for the significance of corporate disclosures. The Signaling Theory, by Spence (1973), indicates that firms can be classified according to dimensions like quality and performance based on the extent of the financial and non-financial information that they disclose in their reports. A high extent of corporate disclosure reduces information asymmetry between the firm and both current and prospective investors, which is likely to improve investors' perceptions of the quality of these firms' financial reports. In terms of the decision on the accounting policy that should be adopted by the firm, Dyczkowska, (2014) argued that the Signaling Theory predicts that companies with high quality reports are more likely to choose accounting policies which allow their superior quality to be disclosed. These companies, he argued, are willing to benefit from open communication with investors in order to signal their competitive advantage. Meanwhile, companies with lower quality reports will attempt to hide these reports and will accordingly make a low level of corporate disclosures (Dyczkowska, 2014).

In addition, the Enterprise Theory by Suojanen (1954) and the Entity Theory by Paton (1962) both emphasize the social responsibility of the firm, since its decisions are likely to affect the majority of stakeholders and regulatory bodies. It thus follows that such parties must be provided with reliable and complete disclosures for them to feel satisfied with the firm's decisions. Another theory backing the importance of corporate disclosures is the Agency Theory (Jensen and Meckling, 1976). Marston and Polei (2004) explain that according to Agency Theory, the separation of ownership and control of a company may be a source of conflict between managers and shareholders. In such cases, managers may be primarily concerned with guarding their own interests as opposed to the interests of the shareholders, thereby possibly leading to agency costs, a decline in the value of the company, and monitoring costs of the supervision of management. According to Aly (2010), disclosure in accounting reports may be an effective method of lowering agency costs, in that, as Watson et al. (2002) explain, disclosure is an effective way of strengthening shareholder trust in management sincerity, thereby decreasing the need for an agent. Not only can this enhance investors' perceptions of the quality of financial reporting, but it can also improve reporting and auditing quality. Likewise, Antle (1982) points to the impact of a good quality audit report on the level of disclosure in financial reporting. According to Antle, the nature of auditors as economic agents may lead to their reports being impacted by post contractual conflict. In turn, this may lead to information asymmetries, which could cause moral issues as a result of improper audits and assessments. 


\section{Research Methods and Sample Selection}

The broad aim of this current study is to provide more in-depth clarification on the impact of DQ on financial reporting quality, audit quality, and investors' perceptions of the quality of financial reporting, especially in the aftermath of the SOX 2002 regulations. Consequently, only empirical studies which were published from 2003 onward, i.e. one year after the commencement of the SOX Act, have been included in this study. This is because, by 2003, it is likely that the SOX rules on corporate disclosures were effective in most publicly held companies. The review commenced with identifying 100 studies on corporate disclosures. However, for quality issues, it was decided to only include studies published in international journals with double-blind review. Hence, the sample was narrowed down to 67 studies. Table 1 classifies these studies based on their authors, their topics, and the journals in which they are published. In addition, these studies have been classified based on the dependent variables financial reporting quality, audit quality, and investors' perceptions of the quality of financial reporting. The search process was based on several keywords, such as quality, corporate disclosure, quality audit, quality reporting, investors' perceptions, earning quality, and financial statements. It was not possible to limit the search process in order to eliminate studies which were conducted in countries that do not implement the SOX Act. Although this may be considered a limitation of this study, it may be argued that many publicly held companies around the globe have been influenced by the SOX regulations without having formally implemented these regulations. Another limitation of this study was the difficulty in comparing the findings of studies conducted before and after the commencement of the SOX regulations. This was due to the existence of different regulatory bodies on corporate disclosures beside the SOX. Whilst a quantitative literature analysis which follows a vote-counting approach places focus on the significant findings and their respective signs, it does not take into account the specific coefficient values. The underlying primary studies are given the expressions significant positive (+) and significant negative (-).

Table 1. Empirical studies on corporate disclosures

\begin{tabular}{|c|c|c|c|}
\hline & \multicolumn{3}{|c|}{ Panel A: Disclosure Quality and its Impact on the Quality of Financial Reporting. } \\
\hline & Authors & Topics & Journals \\
\hline 1 & Alipour et al., (2019) & $\begin{array}{l}\text { The Relationship between Environmental } \\
\text { Disclosure Quality and Earnings Quality. }\end{array}$ & $\begin{array}{l}\text { Journal of Asia Business } \\
\text { Studies. }\end{array}$ \\
\hline 2 & Alzoubi, E.S.S. (2016) & $\begin{array}{l}\text { Disclosure quality and earnings management: } \\
\text { evidence from Jordan. }\end{array}$ & $\begin{array}{l}\text { Accounting } \\
\text { Journal. }\end{array}$ \\
\hline 3 & $\begin{array}{l}\text { Andrikopoulos, } \\
\text { Kriklani, N. (2013) }\end{array}$ & $\begin{array}{l}\text { Environmental Disclosure and Financial } \\
\text { Characteristics of the Firm: The Case of } \\
\text { Denmark. }\end{array}$ & $\begin{array}{l}\text { Corporate } \\
\text { Responsibility } \\
\text { Environmental } \\
\text { Management. }\end{array}$ \\
\hline 4 & $\begin{array}{l}\text { Bartov, } \quad \text { E. and Cohen, } \\
\text { D.A. (2009) }\end{array}$ & $\begin{array}{l}\text { The numbers game in the pre- and } \\
\text { post-Sarbanes-Oxley eras. }\end{array}$ & $\begin{array}{l}\text { Journal of Accounting, } \\
\text { Auditing and Finance. }\end{array}$ \\
\hline 5 & $\begin{array}{l}\text { Bauer, T. and Boritz, J.E. } \\
(2013)\end{array}$ & $\begin{array}{l}\text { Corporate Reporting Awards and Financial } \\
\text { Reporting Quality }\end{array}$ & \\
\hline 6 & $\begin{array}{l}\text { Beattie, V., Mclnnes, B. and } \\
\text { Fearnley, S. (2004) }\end{array}$ & $\begin{array}{l}\text { A methodology for analyzing and evaluating } \\
\text { narratives in annual reports: a comprehensive } \\
\text { descriptive profile and metrics for disclosure } \\
\text { quality attributes. }\end{array}$ & Accounting Forum. \\
\hline 7 & $\begin{array}{l}\text { Beretta, S. and Bozzolan, S. } \\
\text { (2008) }\end{array}$ & $\begin{array}{l}\text { Quality versus quantity: the case of } \\
\text { forward-looking disclosure. }\end{array}$ & $\begin{array}{l}\text { Journal of Accounting, } \\
\text { Auditing \& Finance. }\end{array}$ \\
\hline 8 & $\begin{array}{l}\text { Chandra U, Ettredge ML, } \\
\text { Stone MS. (2006) }\end{array}$ & $\begin{array}{l}\text { Enron - era Disclosure of Off - Balance Sheet } \\
\text { Entities. }\end{array}$ & Accounting Horizons. \\
\hline 9 & $\begin{array}{l}\text { Ching, H.Y., Gerab, F. and } \\
\text { Toste, T.H. (2017) }\end{array}$ & $\begin{array}{l}\text { The Quality of Sustainability Reports and } \\
\text { Corporate Financial Performance: Evidence } \\
\text { From Brazilian Listed Companies. }\end{array}$ & Sage Open Journal. \\
\hline 10 & $\begin{array}{l}\text { Cohen, A.D., Dey, } \\
\text { A. and Lys, Z.T. (2008) }\end{array}$ & $\begin{array}{l}\text { Real and accrual-based earnings management } \\
\text { in the pre- and post-Sarbanes-Oxley periods. }\end{array}$ & The Accounting Review. \\
\hline
\end{tabular}


11 Ghofar, A. and

Saraswati, E. (2009)

12 Jaffar, R., Jamaludin, S. and Rahman, M. (2007)

13 Kiattikulwattana, P. (2014)

14 Lobo, J. (2005a)

J.L. and Zhou,

15 Rezaee, Z. and Tuo, L. (2017)

16 Shiri, MM., Salehi, M. and Radbon, A. (2016)

1 Abbott et al., (2004)

Audit committee characteristics and restatements.

Earnings management and voluntary disclosure of management's responsibility for the financial reports.

To swear early or not to swear early? An empirical investigation of factors affecting CEOs' decisions.

Are the Quantity and Quality of Sustainability Disclosures Associated with the Innate and Discretionary Earnings Quality?.

A Study of Impact of Ownership Structure and Disclosure Quality on Information Asymmetry in Iran.

\section{Panel B: Disclosure Quality and its Impact on Audit Quality}

and

Ahmed

Karim, (2005)

3 Agyei-Mensah (2018)

and Compliance to international accounting standards in Bangladesh: a survey of annual reports.

The effect of audit committee effectiveness and audit quality on corporate voluntary disclosure quality.

$4 \quad$ Alsaeed (2006)

$5 \quad$ Al-Shaer et al. (2017)

6 Arens, et al., (2010)

7 Be'dard, J., Chtourou, S.M. and Courteau, L. (2004)

8 Bepari, M.K. and Mollik, A.T. (2015)

9 Cohen,

J., The corporate governance mosaic and financial Krishnamoorthy, G. \& reporting quality.

The association between firm-specific characteristics and disclosure.

Audit Committee and financial reporting quality: Evidence from UK environmental accounting disclosures.

Auditing and Assurance Services: An Integrated Approach.

The effect of audit committee expertise, independence, and activity on aggressive earnings management Auditing.

Effect of audit quality and accounting and finance backgrounds of audit committee members on firms' compliance with IFRS for goodwill impairment testing.

Wright, A. (2004)

10 Carcello, J. V., \& Li, C. Costs and benefits of requiring an engagement
International Symposium on Finance and Accounting.

Malaysian Accounting Review.

Asian Review of Accounting.

Journal of Accounting and Public Policy.

Journal of Business Ethics.

The Journal for Decision Makers.

Journal of Practice \& Theory.

The Bangladesh

Accounting.

African Journal of Economic and Management studies.

Managerial Auditing Journal

Journal of Applied Accounting Research.

Upper Saddle River, NJ.

A journal of Practice \& Theory.

Journal of Applied Accounting Research.

Journal of Accounting Literature.

Accounting Review. 
(2013)

11 Carcello, J. V., \& Santore, R. (2015)

12 Dao, M., XU, H. and Liu, L. (2019)

13 Ettredge, L. and Elizabeth,

E. (2013)

14 Hoitash, R., Markelevich, Auditor fees and audit quality.

A. and Barragato,

C.A. (2007)

15 Kamolsakulchai, M. (2015)

16 Lee, H., Mande, V. and Ortman, R. (2004)

17 Mande, V. and Son, M. (2015)

18 Mitchell, V.Z., Singh, H. and Singh, I. (2008)

19 Ousama, A.A., Fatima, A.-H. and Hafiz-Majdi, A.R. (2012)

20 Owusu-Ansah, S. and Yeoh, J. (2005)

21 Stanley, J.D. and DeZoort, F.T. (2007)

22 Stewart, J. and Munro, L. (2007)

23 Vafees, N. (2005)

24 Wang, Q., Wong, T.J and Xia, L. (2008)

25 Xie, B., W. Davidson III, and DaDalt, P. (2003)

26 Yuniarti, R. (2011) partner signature: Recent experience in the United Kingdom.

Engagement partner identification: A theoretical analysis.

Impact of the disclosure of audit engagement partners on audit quality: Evidence from the USA.

Fee pressure and audit quality.

The impact of the audit committee effectiveness and audit quality on financial reporting quality of listed company in stocks exchange of Thailand.

The effect of audit committee and board of director independence on auditor resignation.

How Do Auditor Fees Affect Accruals Quality? Additional Evidence.

Association between independent audit committee members' human-resource features and underpricing: the case of Singapore.

Determinants of intellectual capital reporting: evidence from annual reports of Malaysian listed companies.

The effect of legislation on corporate disclosure practices.

Audit firm tenure and financial restatements: an analysis of industry specialization and fee effects.

The Impact of Audit Committee Existence and Audit Committee Meeting Frequency on the External Audit: Perceptions of Australian Auditors.

Audit Committees, Boards, and the Quality of Reported Earnings.

State ownership, the institutional environment, and auditor choice: evidence from China.

Earnings management and corporate governance: The roles of the board and the audit committee.

Audit firms size, audit fee and audit quality.
Accounting Horizons.

International Journal of Auditing.

Accounting, Organization and Society.

Managerial Auditing Journal

Review of Integrative Business \& Economics Research.

Auditing: A Journal of Practice and Theory.

International Journal of Auditing.

Journal of Human Resource Costing \& Accounting.

Journal of Accounting in Emerging Economies.

Abacus, A journal of Accounting, Finance and Business Studies.

Journal of Accounting and Public Policy.

International Journal of Auditing.

Contemporary Accounting Research.

Journal of Accounting and Economics.

Journal of Corporate Finance.

Journal of Global Management. 


\section{Panel C: Disclosure Quality and its Impact on Investors Perceptions}

1 Anctle, R., Dickhaut, J., Information transparency and coordination Kanodia, C. and Shapiro, B. failure: theory and experiment. (2004)

2 Ballas, A.A. \& Tzovas, C. An empirical investigation of Greek firms' (2010)

3 Barth, M., Landsman, W. and Lang, M. (2008)

4 Birkey, R.N., Guidry, R.P., Islam,

M.A. and Patten,

D.M. (2016)

5 Blanc, R., Patten, D.M., and Branco, M.C. (2016)

6 Bowerman, S. and Sharma, U. (2016)

7 Chau, G. \& Gray, S. (2010)

8 De Klerk, M., Van Staden, Ch. J., and De Villiers, Ch. (2015)

9 De Villiers, C. and Van Staden, C.J. (2010)

10 De Villiers, C. and Van Staden, C.J. (2012)

11 Florpouls, I. (2006)

12 Glennie, M. and Lodhia, S. (2013)

13 Jaffar, R., Jamaludin S. and Rahman, M. (2007)

14 Kansal, M., Joshi, M. and Batra, G.S. (2014)

15 Latridis, G. \& Alexakis, P. (2012)

16 Lawrence, S.R., Botes, V., Collins, E. and Roper, J. (2013) purely self-interested or as socially responsible? compliance with IFRS disclosure requirements.

Journal of Accounting Research.

International Journal of Management and Financial Accounting.

Journal of Accounting Research.

Journal of Business Ethics. response to the California transparency in supply chains act of 2010 .

Market Reactions to Transparency International Reports on Corporate Anti-Corruption.

The effect of corporate social responsibility disclosures on share prices in Japan and the UK.

Accounting and the Public Interest.

Corporate Ownership and Control.

Journal of International Accounting, Auditing and Taxation.

Pacific

Accounting

Review.

Shareholders' requirements for corporate environmental disclosures: a cross country comparison.

New Zealand shareholder attitudes towards corporate environmental disclosure.

IAS - First time users: Some empirical evidence from Greek Companies.

Pacific

Accounting

Review.

Spoudai

Meditari

Accountancy on corporate-community partnership agenda, An Australian case study.

Determinant factors affecting quality of reporting in annual report of Malaysian companies.

Determinants of Corporate Social Responsibility Disclosures: Evidence from India.

Research.

Malaysian

Accounting Review

\section{Advances in Accounting}

Review of Accounting and Finance

Meditari Accountancy

Research 
17 Leventis, S. and Weetman, Impression management: dual language reprinting P. (2004a)

18 Murray, A., Sinclair, D., Power, D., and Rray, R., (2006)

19 Ronald P.G. and Dennis M.P. (2010)

20 Samkin, G. (2012)

21 Sankara, J., Dennis Patten, Deborah Lindberg, (2019)

22 Shiri, MM., Salehi, M. and Radbon, A. (2016)

23 Solomon, J.F. and Solomon, A. (2006)

24 Summerhays, K. and De Villiers, C. (2012)

25 Tslavotas, I. and Dionysiou, D. (2011) and voluntary disclosure.

Do financial markets care about social and environmental disclosure?: Further evidence and exploration from the UK.

Market reactions to the first - time issuance of corporate sustainability reports: Evidence that quality matters.

Changes in sustainability reporting by an African defense contractor: a longitudinal analysis.

M. Mandated social disclosure: Evidence that L. investors perceive poor quality reporting as increasing social and political cost exposures.

A Study of Impact of Ownership Structure and Disclosure Quality on Information Asymmetry in Iran.

Private, Social ethical and environmental disclosure. Accounting.

Oil company annual report disclosure responses to the 2010 Gulf of Mexico oil spill.

Value relevance of IFRS mandatory disclosure requirements.
Accounting Forum

Accounting, Auditing \& Accountability Journal

Sustainability Accounting, Management and Policy Journal

Meditari Accounting

Research

Sustainability Accounting, Management and Policy Journal

The Journal for Decision Makers.

Auditing \& Accountability Journal, Vol. 19 No. 4, pp. 564-591.

Journal of the Asia-Pacific Centre for Environmental Accountability

Journal of Applied Accounting Research

\section{A Survey of Published Research on Corporate Disclosures}

Companies may present financial and non-financial disclosures in their financial statements, notes to the financial statements, management discussion and analysis, and on other legal reports. Some companies may even choose to disclose information in management forecasts and the press (Shiri et al., 2016). Whilst some companies follow traditional, paper-based methods of disclosure, other companies may opt for online reporting due to it being more time and cost effective (Ojah \& Mokoteli, 2012; Andrikopoulos \& Kriklani, 2013). Several empirical studies on corporate disclosures have been conducted in the past two decades. These studies have discussed several issues, such as the potential determinants of disclosures, which are mainly based on a firm's characteristics (see for example: Khlif and Souissi, 2010; Aly et al., 2010; Al-Htaybat, 2011); mandatory and voluntary disclosure (Wang et al, 2015; Uyar et al., 2013; Niléhn and Thoresson (2014); Shiri et al., 2016; Lim et al., 2017); financial and non-financial disclosure (Arvidsson, 2011); corporate governance disclosure (Gandia, 2008); and social and environmental disclosure (Magness, 2006; Fatima et al., 2015; Al-Shaer et al., 2017; Alipour et al., 2019). These studies have used different theoretical perspectives which set concrete and explanatory grounds for corporate disclosures. These theories include the Entity Theory (Paton, 1962), Enterprise Theory (Suojanen, 1954), Regulatory Capture Theory (Posner, 1974), The User's Cognitive Learning Process (Hodge et al, 2002), Information Foraging Theory (Piroli and Card, 1999), Information Overload Theory (Rao, 2002), Quantum Theory (Orlowski's, 2003), Post Modern Communication Theory (Massumi, 1987), Upper Echelons Theory (Hambrick and Mason, 1984), Innovation Diffusion Theory (Meyer et al, 1983), Signaling Theory (Spence, 1973), and the Agency Theory. 
A literature review by Oyelere et al. (2003) takes into account almost 30 disclosure studies and explains the variables, methodology, and findings for each case. The review findings show that traditional financial reporting and the voluntary use of Internet financial Reporting (IFR) share several determinants, including firm size, liquidity, industrial sector, and spread of shareholding. Meanwhile, characteristics such as leverage, profitability, and internationalization are not determinants for the voluntary use of IFR. Al-Htaybat (2011) classified empirical studies on corporate disclosures based on research objectives into first- and second-generation studies. The first-generation studies were mainly descriptive surveys assessing whether companies have websites, and if so, whether they use their websites to disclose financial and non-financial information. The second-generation studies, according to Al-Htaybat (2011), began in the early 2000s, and the broad aim of these studies was to measure the level of financial disclosure by using a disclosure checklist and examining factors, such as company characteristics, that were based on agency and signaling theories.

It is evident that corporate disclosure has received remarkable attention from researchers worldwide, since a high volume of studies on a variety of issues related to this topic have been conducted in the past two decades. Seeing as the topic of corporate disclosure is already widely discussed, boundaries of particular variables need to be placed in order for this study to maintain its relevance and objectivity and to make an effective contribution to the discussion. Therefore, the current study reviews the literature on corporate disclosures with the aim of determining the effect of disclosure quality on financial reports quality, audit quality, and investors' perceptions of the quality of financial reports.

\subsection{Quality of Financial Reporting}

After the Enron, WorldCom, and Parmalat major corporate scandals (Ghofar and Saraswati, 2009; Andrikopoulos and Kriklani, 2013) and the 2007 global financial crisis (Chandra et al., 2006), more focus began to be placed on quality reporting. Consequently, investors, regulators, and public companies began to take further efforts to attach good quality disclosures to their financial reports, in the aim of enhancing the honesty and reliability of financial reporting. Rezaee and Tuo (2017) identified a positive relationship between sustainable disclosure quantity and innate earnings quality, whilst they identified a negative correlation between disclosure quantity and discretionary earnings quality in reducing managerial earnings manipulation and unethical opportunistic reporting behavior. In the same vein, Beretta and Bozzolan (2008) found a positive correlation between disclosure quantity and the quality of financial reporting, in that quantity measures may be utilized as proxy for DQ and may help analysts predict earnings.

Similarily, Ching et al. (2017) studied the correlation between the quality of information disclosed in the sustainability reporting quality and financial performance. Data was taken from all Brazilian companies listed in the period from 2008 to 2014. The study results indicated the presence of a neutral relationship between disclosure quality of sustainable reporting and corporate financial performance, thereby contradicting the study results of Beretta and Bozzolan (2007) and Rezaee and Tuo (2017). Ching et al. (2017) argue that this neutral correlation may be due to the fact that profits from socially responsible conduct compensate for the cost in a market equilibrium. Another alternative explanation for this neutral correlation is the view by stakeholders that the firm's social and environmental activities are legitimate. It may also be the case that some companies may utilize expensive sustainability initiatives in the aim of reducing the level of information asymmetry.

Several scholars, such as Stolowy and Lebas, 2002; Beattie et al., 2004; Jaffar et al., 2007; and Alzoubi, 2016, utilized different methods of measuring quality reporting as a dependent variable, such as examining the effect of DQ on earnings management as a dependent variable. Stolowy and Lebas (2002) and Jaffar et al. (2007) argued that whilst investors require disclosure of financial and non-financial information for the decision-making process, some extra information disclosure may be necessary. This is because management may otherwise keep some information regarding reported earnings confidential and may control the type and quantity of the information which they choose to disclose. Managers may do this through certain accounting procedures, such as asset write-off, rating exceptional items, and treating discretionary accruals as a part of earnings management (EM) activities (Jaffar et al., 2007; Stolowy and Lebas, 2002). The researchers argued that since such practices may reduce financial reporting quality (FRQ) and thus decrease investors' trust of financial reports, it may be worthwhile that companies disclose voluntary information to investors.

A study by Kiattikulwattana (2014) examined the connection between the disclosure of the management's responsibility for the financial reports (MFR) and the management of both accrual and real earnings in the publicly held companies of Thailand. The collected data showed that MFR disclosure is not in any way connected to activities related to discretionary accrual and real earnings management and that it does not stop 
firms from manipulating their earnings. On the other hand, a study by Alzoubi (2016) investigated the impact of disclosure quality (DQ) on earnings management (EM) in firms listed in the Amman Stock Exchange in Jordan. The study, which was carried out on a sample of 86 Jordanian industrial companies listed between 2007 and 2010, utilized the cross-sectional version of the modified Jones model and generalized least square reg ression. The study results revealed that as the level of disclosure increased, the level of the magnitude of (EM) decreased, thus leading to enhanced financial reporting quality. These findings are similar to those by Lobo and Zhou, 2005; Cohen et al., 2008; Bartov and Cohen, 2009, and Shiri et al., 2016. Studies by these scholars revealed a negative correlation between disclosure quality and quality reporting and showed that information asymmetry is reduced when reliable and timely information is disclosed. On the other hand, firms with a highly ownership-oriented structure, a high level of institutional ownership, and a low level of disclosure quality showed higher levels of information asymmetry. A study by Alipour et al., (2019) showed similar findings. The study investigated the effect of corporate environmental disclosure on earnings quality in Iranian non-financial companies, and the findings revealed a positive connection between environmental disclosure quality and earnings quality.

Baur and Boritz (2013) suggest that if companies take part in financial reporting awards, that would allow them to indirectly indicate the quality of their earnings. Further, higher earnings quality may even increase a company's chances of winning these awards. Even though the study did not prove a relationship between higher earnings quality and an increased chance of winning financial reporting awards, the ability to participate is an indication of a firm's earnings quality.

\subsection{Audit Quality}

Good quality audit reports may be required in cases where agency problems connected to ownership and control segregation arise. Increased audit quality works to reduce information asymmetry and conflict of interest between managers and shareholders (Arens et al., 2010). Hence, the process of auditing is seen to work as a monitoring mechanism which assists in enhancing the quality of disclosure (Agyei-Mensah, 2018). There are remarkable empirical studies that have emphasized the link between DQ and audit quality (see for example Arens et al., 2010 and Al-Shaer et al., 2017). Other studies have identified the impact of the audit committee on both audit and disclosure quality (see for example, Stewart and Munro, 2007; Vafeas, 2005; Owusu-Ansah and Yeoh, 2005; Lee et al., 2004; Bedard, 2004; Xie, et al. 2003; and DeZoort, 2002). These studies have identified the positive impact of certain characteristics of the audit committee on the audit committee's effectiveness and, accordingly, on the quality of corporate disclosures. These audit committee characteristics include size, frequency of meetings, and member experience,

DeZoort (2002) argues that the audit committee functions as a subcommittee of the board of directors, which is usually in charge of operating financial reporting, auditing, and enabling communication between auditors and the board of directors. He also argues that a large audit committee is more effective than a small one. This is supported by Vafeas (2005), who states that firms can improve the quality of their financial statements by structuring and operating their audit committees more appropriately. In addition, Kamolsakulchai (2015) finds an audit committee of good size is likely to lead to higher quality financial reporting monitoring and financial reporting. Similarly, Abbott et al. (2004) identified a positive link between certain audit committee characteristics, such as independence, financial expertise, and frequent meetings, and both audit quality and the quality of financial statement disclosure. In the same vein, Stewart and Munro (2007) investigated the effect of the frequency of audit committee meetings and auditor attendance at meetings on audit quality. Based on an experimental design study, they found that these independent variables are highly related to a decrease in the perceived level of audit risk. They also found that the responsibilities of the audit committee include providing help in resolving conflicts with management and improving the overall level of audit quality.

Al-Shaer et al., (2017) provide evidence from the UK environmental disclosures of a positive association between an effective audit committee and both the quantity and quality of social and environmental disclosures. Their evidence suggests that whilst a good audit committee is likely to enhance the quality of environmental accounting disclosures, it does not impact the quantity of these disclosures. This result is consistent with the results reached by Cohen, et al. (2004) and Mitchell et al. (2008). The former argued that the responsibilities of the audit committee include hiring auditors and examining their performance, as well as assessing the effect of audit quality on financial reporting. Meanwhile, the latter (Mitchell et al. 2008) showed a positive relationship between audit quality, the audit committee, and disclosure quality. They argued that a good audit committee is likely to improve audit quality, therefore improving the quality of published financial reports. This result is supported by Mensah, (2018), who provides evidence of the substitute and complementary effect between the presence of 
external auditors and an effective audit committee in enhancing voluntary disclosure quality. He also found that both the board size and profitability may be influencing factors on the quality of voluntary disclosure.

In addition, other studies have investigated the link between audit and disclosure quality and the size of both audit firms and audit fees. Wang et al. (2008) examined the impact of the size of an audit firm on its level of disclosures. Companies with a high level of disclosure quality were found to be associated with large audit firms (e.g. the Big Four audit firms), as these firms tend to implement stricter and more extensive standards in order to preserve their independence and avoid any risk of harming their reputation. This is in line with the findings of Kamolsakulchai (2015), which show that an audit firm which is large in size is likely to provide a high level of disclosure quality. Bepari and Mollik (2015) show that audit quality is vital for increasing the transparency, compliance, and quality of a company's financial reports. Ahmed and Karim (2005) posit that the services of the Big Four audit firms are more likely to abide by reporting standards in a stricter manner than other audit firms. These firms are also more likely to encourage companies to make voluntary disclosures in order to meet the requirement of understandability.

In terms of audit fees, Hoitash et al., 2007 and Stanley and DeZoort, 2007 found a negative correlation between audit fees and the possible manipulation of financial statements. Thus, the higher the audit fee, the better the audit quality, and this is in line with the findings of Yuniarti, 2011 and Ettredge et al., 2013. Yuniarti (2011) showed a positive correlation between audit fees and audit quality, and Ettredge et al. (2013) posited that a low audit fee results in low audit quality. However, these results were contradicted by Mande and Son, 2015; Alsaeed, 2006; and Ousama et al. (2012). Mande and Son, 2015 examined the extent to which the Sarbanes - Oxley Act (SOX) diminishes the link between auditor fees and accruals quality. The study sample consisted of a large number of companies, and the results showed novel conclusions on the effect of SOX on auditor fees and audit quality. They claim that post - SOX, the association between audit fees and audit quality weakened or even disappeared in some specifications. Meanwhile, Alsaeed, 2006 and Ousama et al. 2012 did not find any notable connection between audit fees and audit quality.

Additionally, previous studies show that disclosing audit partners' names in financial reports has a positive impact on audit quality. For example, Dao et al., (2019) examine the impact that the disclosure of audit partners' names in American public company reports has on audit quality. Abnormal accruals and the probability of detecting material weaknesses in internal control were used as the measures of audit quality, and it was found that disclosure of audit partners' names may reduce the level of abnormal accruals and increase the company's chances of detecting material weaknesses in internal control. Disclosure of audit partners' names was also found to increase the levels of auditor accountability, transparency, and, accordingly, audit quality. These results are supported by the findings of Carcello and Li (2013) and Carcello and Santore (2015). The findings of these studies all identified a positive relationship between the disclosure of audit partners' names in financial reports and an increased quality of auditing and financial reporting.

\subsection{Disclosure Quality and Investors' Perceptions of the Quality of Financial Reporting.}

The response of investors to DQ is vital for examining the impact of DQ on investors' perceptions of the quality of financial reporting. Disclosure quality is a good mechanism for mitigating information asymmetry and increasing trust between management and investors (Shiri et al., 2016). DQ is a vital factor in highly developed capital markets, as it assists capital providers in assessing the prospective returns of investment opportunities and monitoring the operation of capital (Shiri et al., 2016). Thus, supplementary financial reporting procedures are necessary for improving investors' perceptions and trust of financial reports (Jaffar et al., 2007). Often, investors may be hesitant towards equity markets as a result of the low level of communication between managers and investors (Chau and Gray, 2010) and the poor level of disclosure in company reports (Tower et al., 2011; Kansal et al., 2014). Hence, publicly held companies should disclose how they manage their resources through providing any information which may assist investors in the decision-making process (Jaffar et al., 2007).

Investors' perceptions have been examined through identifying the effect of long-term market valuation, firm turnover, and share prices. Several researchers have examined the link between DQ and the above-mentioned issues. Vrentzou 2005; Floropoulos 2006; Ballas and Tzovas, 2010; Leventis and Weetman, 2004a; and Tsalavoutas and Dionysiou, 2011 noted that disclosure quality correlates positively with share trading volume and a firm's market value. Meanwhile, Jones et al. (2007) note a weak yet negative correlation between disclosure and long-term market valuation effects. On the other hand, Holm and Rikhardsson (2008) note a positive relationship between environmental performance disclosure and the investment choice s of investors. Further, Latridis and Alexakis (2012) investigate the incentives for the issuing of voluntary 
disclosures and the financial differences between voluntary and non - voluntary disclosures. They also examine the association between the provision of voluntary disclosures and earnings management. Their study shows that providing voluntary accounting disclosures is positively linked to increased share trading volume and market value, whilst it is negatively linked to earnings management. This is consistent with Anctil et al. (2004), who found that voluntary disclosures may signify lower earnings management, thus decreasing the level of information uncertainty and satisfying investors' need for information. However, Latridis and Alexakis (2012) argue that firms might make voluntary disclosures with the intention of deceiving investors and concealing certain earnings management activities.

In the same vein, Murray et al. (2006) utilized a sample from the UK and Jones et al. (2007) utilized a sample from Australia to examine the impact of corporate social responsibility disclosure on long-term market valuation effects. Murray et al. (2006) investigated the reactions of stock market participants in the UK to the social and environmental disclosures of the largest 100 companies, selected on a turnover basis. They undertook a series of tests to explore the impact of disclosures on share price behavior. The association tests yielded no evident impact; meanwhile, the study identified a positive association between company returns over time and the level of certain types of disclosures. This is in parallel with Barth et al. (2008), who concluded that disclosing accounting items and information on recognition in financial statements enhances the perceptions and expectations of current investors and attracts potential investors.

In terms of the link between the level of disclosure and share prices, previous studies show that investors across different countries hold the view that environmental information is valuable and relevant. In the UK, De Klerk et al. (2015) and Bowerman and Sharma (2016) found that higher levels of corporate social responsibility (CSR) disclosures are linked to increased share prices. Furthermore, the study show ed that the environmental sensitivity of the industry in which a firm operates is an influencing factor on the link between CSR disclosures and share prices. This is consistent with Solomon and Solomon (2006) and De Villers and Van Staden (2010), who found that Australian, American, and British investors hold the view that environmental disclosure assists investors in the decision-making process. This is also consistent with Hewage (2015) in Sri Lanka, De Villiers and Van Staden (2012) and Lawrence et al. (2013) in New Zealand, Glennie and Lodhia (2013) in Australia, Summerhavays and De Villiers (2012) in Mexico, and Samkin (2012) in South Africa.

Alongside market - based methods, experimental designs have also been used by researchers to explore the impact of DQ on investors' perceptions of financial reporting. Birkey et al. (2016) and Blanc et al, (2016) provide evidence of a positive relationship between social responsibility disclosures and investors' reactions to these disclosures. Sankara, et al., (2019) examined the effect of the poor observation of mandated social disclosure reporting standards on market reactions. Based on a sample from US publicly held companies, the analysis reveals that firms with higher levels of disclosure experienced a lower number of negative market reactions. This is even more evident among smaller firms and firms operating in industries with a high level of social exposure. The study also shows that feelings of concern regarding potential political costs arising from poor quality reporting may elicit negative responses from investors. This result supports Roland and Dennis (2010), who examine US market shareholder views regarding the usefulness of publishing a standalone sustainability report. Further, the study investigates the extent to which market reactions are influenced by sustainability report quality. The study utilized a sample of 37 American firms which had issued their initial sustainability report between 2001 and 2008, and the results showed that, generally, issuing sustainability reports did not elicit any notable market reactions. Meanwhile, the cross - sectional analysis revealed that the reactions of investors correlate positively with report quality, in that the higher the quality of the reports, the more positive the market reactions.

\section{Conclusion and Discussion}

This study reviews the literature on accounting disclosures. It explores the link between disclosure quality and financial reporting quality, audit quality, and investors' perceptions of the quality of financial reporting. For the purpose of analysis in this study, disclosure quality has been considered as an independent variable, while the remaining three variables have been considered as dependent variables. The analysis reveals that recent regulations of the Sarbanes Oxley Act (2002) have significantly increased management awareness of the importance of accounting disclosures. This has encouraged the management teams of publicly held companies to place strong emphasis on attaching financial and non-financial disclosures of a high quality to their financial reports. The broad 
aims of this are to ensure the honesty and reliability of these reports and to mitigate the existence of information asymmetry between managers and stakeholders.

In general, the majority of the studies which have been reviewed identified the presence of a positive link between disclosure quality and financial reporting quality, audit quality, and investors' perceptions of the quality of financial reporting. The analysis shows a positive correlation between the quantity of information disclosed and the quality of financial reporting. This positive correlation mitigates managerial earnings manipulation and unethical opportunistic reporting behavior. Hence, the quantity measures might be utilized as proxy for disclosure quality and may help analysts predict earnings. Moreover, the analysis shows that firms which disclose reliable and timely information usually have a low level of asymmetric information between management and investors. However, firms which have a high level of ownership-oriented structure, a high level of institutional ownership, and a low level of disclosure quality are more likely to see an increase in information asymmetry. In addition, consistent with the signaling theory, this study shows that firms which perform well financially are likely to convey this in their financial reports, while firms with moderate financial performance might be reluctant to make sufficient disclosures.

In terms of the link between DQ and audit quality, the findings of this study show a reciprocal association between these two variables. The auditing process may be viewed as a monitoring tool which enhances voluntary disclosure quality. Agency problems related to the relationship between auditors and shareholders call for a high level of audit quality. The findings shed light on the substitute and complementary relationship between good audit quality and the increase in voluntary disclosure quality. This argument, according to the literature reviewed, is based on the fact that larger audit firms tend to implement stricter and more extensive standards in order to preserve their independence and avoid any risk of harming their reputation. These firms are also more likely to show more concern towards the disclosures of their clients and to encourage companies to make voluntary disclosures in order to meet the requirement of understandability.

Moreover, the literature reviewed shows that high audit quality and high disclosure quality are important for gaining the trust of investors and improving their perceptions of financial reporting. They are also necessary for reducing the uncertainty of investors towards the firm's market value, the firm's turnover, and share prices. This study shows that disclosure quality is positively related to share trading volume and a firm's market value and that corporate social responsibility and environmental disclosures are linked to higher returns and share prices. A remarkable number of studies have emphasized that voluntary disclosures may signify lower earnings management, thus providing investors with the necessary level of information. However, some scholars argue that this should be considered with caution, since some firms might make voluntary disclosures in order to deceive investors and conceal certain earnings management activities.

Finally, our results contribute to the body of research on accounting disclosure by providing an insight into the link between disclosure quality and financial reporting quality, audit quality, and investors' perceptions of the quality of financial reporting. Our study also presents a thorough discussion on disclosures and outlines a future research avenue. It shows that most of the literature on accounting disclosures has been conducted in developed countries. More research on this issue is needed to be conducted in developing countries, especially since most of these countries have emerging markets. In addition, many of these countries have recently started to apply IFRS throughout the financial reporting process, which calls for the need to investigate the effect of IFRS on accounting disclosure in these countries. Moreover, the findings of this study highlight the impact of the audit committee on audit and disclosure quality. Therefore, more research is needed to find out the impact of some independent variables related to audit committee characteristics such as size and the qualifications and experience of the committee members.

\section{References}

Abbott, L., S. Parker, \& Peters, G. (2004). Audit committee characteristics and restatements. Auditing: A Journal of Practice \& Theory, 23(1), 69 - 88. https://doi.org/10.2308/aud.2004.23.1.69.

Ahmed, J. \& Karim, W. (2005). Compliance to international accounting standards in Bangladesh: a survey of annual reports. The Bangladesh Accounting, 40(1), 23-24. https://doi.org/10.2308/aud.2004.23.1.69.

Akman, N.H. (2011). The effect of IFRS adoption on financial disclosure: Does culture still play a role? Amarican International Journal of Contemporary Research, 1(1).

Al-Htaybat Kh. (2011). Corporate online reporting in 2010: a case study in Jordan. Journal of Financial Reporting \& Accounting, 9(1), 5-26. DOI: 10.1108/19852511111139778. 
Alipour, M., Ghanbari, M., Jamshidinavid, B. \& Taherabadi, A. (2019). The Relationship between Environmental Disclosure Quality and Earnings Quality : A panel study of an Emerging Market. Journal of Asia Business Studies. https://doi.org/10.1108/JABS-03-2018-0084.

Alsaeed. (2006). The association between firm-specific characteristics and disclosure. Managerial Auditing Journal, 21(5). https://doi.org/10.1108/02686900610667256.

Al-Shaer, H., Salama, A. \& Toms, S. (2017). Audit Committee and financial reporting quality: Evidence from UK environmental accounting disclosures. Journal of Applied Accounting Research, 18(1), 2-21. https://doi.org/10.1108/JAAR-10-2014-0114

Alzoubi, E.S.S. (2016). Disclosure quality and earnings management: evidence from Jordan. Accounting Research Journal, 29(4), 429-456. https://doi.org/10.1108/ARJ-04-2014-0041.

Aly D., Simon J. \& Hussainey Kh. (2010). Determinants of corporate internet reporting: evidence from Egypt. Managerial Auditing Journal, 25(2). https://doi.org/10.1108/02686901011008972.

Andreas A, Anna, A. M. \& Andreas G. M. (2016). Financial Disclosure in the Travel and Leisure Industry. International Journal of Tourism Research, 18(6). https://doi.org/10.1002/jtr.2078.

Anctle, R., Dickhaut, J., Kanodia, C. \& Shapiro, B. (2004). Information transparency and coordination failure: theory and experiment. Journal of Accounting Research, 42(2), 159-95. https://doi.org/10.1111/j.1475-679X.2004.00134.x.

Antle, R. (1982). The Auditor as an Economic Agent. Journal of Accounting Research, 20(2), 503-527.

Arens, A., Elder, R. \& Beasley, M. (2010). Auditing and Assurance Services: An Integrated Approach. Prentice Hall, Upper Saddle River, NJ. [Google Scholar].

Arikopoulos, A. \& Kriklani, N. (2013). Environmental Disclosure and Financial Characteristics of the Firm: The Case of Denmark. Corporate Social Responsibility and Environmental Management, 20(1), 55-64. https://doi.org/10.1002/csr.1281.

Arvidsson, S. (2011). Disclosure on non-financial information in the annual reports: A management team perspective. Journal of Intellectual Capital, 12(2), 277-300. https://doi.org/10.1108/14691931111123421 .

Ballas, A.A. \& Tzovas, C. (2010). An empirical investigation of Greek firms' compliance with IFRS disclosure requirements. International Journal of Management and Financial Accounting, 2(1), 40-62. DOI: 10.1504/IJMFA.2010.032489.

Barth, M., Landsman, W. \& Lang, M. (2008). International accounting standards and accounting quality. Journal of Accounting Research, 46(3), 467-98. https://doi.org/10.1111/j.1475-679X.2008.00287.x.

Bartov, E. \& Cohen, D.A. (2009). The numbers game in the pre- and post-Sarbanes-Oxley eras. Journal of Accounting, Auditing and Finance, 24(4), 505-534. https://doi.org/10.1177/0148558X0902400401.

Bauer, T. \& Boritz, J.E. (2013). Corporate Reporting Awards and Financial Reporting Quality. https://ssrn.com/abstract=1534598.

Beattie, V., Mclnnes, B. \& Fearnley, S. (2004). A methodology for analyzing and evaluating narratives in annual reports: a comprehensive descriptive profile and metrics for disclosure quality attributes. Accounting Forum, 28(3), 205-236. https://doi.org/10.1016/j.accfor.2004.07.001.

Be'dard, J., Chtourou, S.M. \& Courteau, L. (2004). The effect of audit committee expertise, independence, and activity on aggressive earnings management Auditing. A journal of Practice \& Theory, 23(2), 13-35. https://doi.org/10.2308/aud.2004.23.2.13.

Ben Kwame Agyei-Mensah. (2019). The effect of audit committee effectiveness and audit quality on corporate voluntary disclosure quality. African Journal of Economic and Management Studies, 10(1), 17-31, https://doi.org/10.1108/AJEMS-04-2018-0102.

Bepari, M.K. \& Mollik, A.T. (2015). Effect of audit quality and accounting and finance backgrounds of audit committee members on firms' compliance with IFRS for goodwill impairment testing. Journal of Applied Accounting Research, 16(2), 196-220, available at: https://doi.org/10.1108/JAAR-05-2013-0038.

Beretta, S. \& Bozzolan, S. (2008). Quality versus quantity: the case of forward-looking disclosure. Journal of Accounting, Auditing \& Finance, 23(3). https://doi.org/10.1177/0148558X0802300304. 
Birkey, R.N., Guidry, R.P., Islam, M.A. \& Patten, D.M. (2016). Mandated social disclosure: an analysis of the response to the California transparency in supply chains act of 2010. Journal of Business Ethics, https://doi.org/10.1007/s10551-016-3364-7.

Bischof J, Daske H. (2013). Mandatory Disclosure, Voluntary Disclosure and Stock Market Liquidity: Evidence from the EU Bank Stress Tests. Journal of Accounting Research, 51(5), 997 - 1029. https://doi.org/10.1111/1475-679X.12029.

Blanc, R., Patten, D.M., \& Branco, M.C. (2016). Market Reactions to Transparency International Reports on Corporate Anti-Corruption. Accounting and the Public Interest, 16(1), 84-99. https://doi.org/10.2308/apin-51680.

Botosan, C. (1997). Disclosure level and the cost of equity capital. The Accounting Review, 72(3), 323-349.

Bowerman, S. \& Sharma, U. (2016). The effect of corporate social responsibility disclosures on share prices in Japan and the UK. Corporate Ownership and Control, 13(2), 202-216.

Camfferman, K. \& Cooke, T.E. (2002). An analysis of disclosure in the annual reports of UK and Dutch companies. Journal of International Accounting Research, 1(1), 3-30. https://doi.org/10.2308/jiar.2002.1.1.3.

Carcello, J. V., \& Li, C. (2013). Costs and benefits of requiring an engagement partner signature: Recent experience in the United Kingdom. Accounting Review, 88(5), 1511-1546. https://doi.org/10.2308/accr-50450.

Carcello, J.V. \& Neal, T.L. (2003). Audit committee independence and disclosure: choice for financially distressed firms. Corporate Governance, 11(4), 289-299. https://doi.org/10.1111/1467-8683.00327.

Carcello, J. V., \& Santore, R. (2015). Engagement partner identification: A theoretical analysis. Accounting Horizons, 29(2), 297-311. https://doi.org/10.2308/acch-50991.

Chandra U, Ettredge ML, Stone MS. (2006). Enron - era Disclosure of Off - Balance Sheet Entities. Accounting Horizons, 20(3), 231 - 252. https://doi.org/10.2308/acch.2006.20.3.231.

Charles H. Cho, Freedman, M. \& Patten D. M. (2012). Corporate disclosure of environmental capital expenditures: A test of alternative theories. Accounting, Auditing \& Accountability Journal, 25(3), 486-507, https://doi.org/10.1108/09513571211209617.

Chau, G. \& Gray, S. (2010). Family ownership, board independence and voluntary disclosure: Evidence from Hong Kong. Journal of International Accounting, Auditing and Taxation, 19(2), 93-109. http://dx.doi.org/10.1016/j.intaccaudtax.2010.07.002.

Ching, H.Y., Gerab, F. \& Toste, T.H. (2017). The Quality of Sustainability Reports and Corporate Financial Performance: Evidence From Brazilian Listed Companies. Sage Open Journal, 7(2). https://doi.org/10.1177/2158244017712027.

Cohen, J., Krishnamoorthy, G. \& Wright, A. (2004). The corporate governance mosaic and financial reporting quality. Journal of Accounting Literature, 23, 87 - 152. http://ssrn.com/abstract=1086743.

Cohen, A.D., Dey, A. \& Lys, Z.T. (2008). Real and accrual-based earnings management in the pre- and post-Sarbanes-Oxley periods. The Accounting Review, 83(3), 757-787. https://doi.org/10.2308/accr.2008.83.3.757.

Dao, M., XU, H. \& Liu, L. (2019). Impact of the disclosure of audit engagement partners on audit quality: Evidence from the USA. International Journal of Auditing, http://1110845di.y.https.doi.org.kau.proxy.deepknowledge.io/10.1111/ijau.12149.

De Klerk, M., Van Staden, Ch. J., \& De Villiers, Ch. (2015). The influence of corporate social responsibility disclosure on share prices. Pacific Accounting Review, 27(2), 208-228. DOI: 10.1108/PAR-05-2013-0047.

De Villiers, C. \& Van Staden, C.J. (2010). Shareholders' requirements for corporate environmental disclosures: a cross country comparison. British Accounting Review, 42(4), 227-240. https://doi.org/10.1016/j.bar.2010.08.002.

De Villiers, C. \& Van Staden, C.J. (2010). Shareholders' requirements for corporate environmental disclosures: a cross country comparison. British Accounting Review, 42(4), 227-240. https://doi.org/10.1016/j.bar.2010.08.002.

De Villiers, C. \& Van Staden, C.J. (2012). New Zealand shareholder attitudes towards corporate environmental disclosure. Pacific Accounting Review, 24(2), 186-210. DOI: 10.1108/01140581211258470. 
Drake, M.S., Myers, J.N. \& Myers, L.A. (2008). Disclosure Quality and the Mispricing of Accruals and Cash Flow. Journal of Accounting, Auditing \& Finance, August 2008. https://doi.org/10.1177\%2F0148558X0902400303.

Dunn, K.A. \& Mayhew, B.W. (2004). Audit firm industry specialization and client disclosure quality. Review of Accounting Studies, 9(1), 35-58. DOI: 10.1023/B:RAST.0000013628.49401.69.

Dyczkowska, j. (2014). Assessment of quality of internet financial disclosures using a scoring system : a case of Polish stock issuers, 13(1), 50-81.

Ettredge, M., Chan, L. \& Elizabeth, E. (2013). Fee pressure and audit quality. Accounting, Organisation and Society, 39(4). https://doi.org/10.1016/j.aos.2014.04.002.

Fatima, A.H., Abdullah, A., Sulaiman, M. (2015). Environmental disclosure quality: examining the impact of the stock exchange of Malaysia's listing requirements. Social Responsibility Journal, 11(4), 904-922, https://doi.org/10.1108/SRJ-03-2014-0041.

Florpouls, I. (2006). IAS - First time users: Some empirical evidence from Greek Companies. Spoudai, 56(3), 39-70.

Gandia, J. L. (2008). Determinants of internet based corporate governance disclosure. Online Information Review, 32(6). https://doi.org/10.1108/14684520810923944.

Ghofar, A. \& Saraswati, E. (2009). Problems in financial reporting: the analysis of quality of disclosure and the measurement system of the traditional accounting. International Symposium on Finance and Accounting. http://papers.ssrn.com/sol3/papers.cfm?abstract_id=1802916.

Glennie, M. \& Lodhia, S. (2013). The influence of internal organisation; factors on corporate-community partnership agenda, An Australian case study. Meditari Accountancy Research, 21(1), 52-67. https://doi.org/10.1108/MEDAR-07-2012-0022.

Hambrick, D. \& Mason, P. (1984). Upper echelons: the organization as a reflection of its top managers. Academy of Management Review, 9(2), 193-206. http://www.jstor.org/stable/258434?origin=JSTOR-pdf.

Hodge, F. Kennedy, M. \& Maines, L. (2002). Recognition Versus Disclosure in Financial Statements: Does Search-facilitating technology improve transparency? Working Paper, University of Washington, Seattle, WA.

Hoitash, R., Markelevich, A. \& Barragato, C.A. (2007). Auditor fees and audit quality. Managerial Auditing Journal, 22(8), 761-786. https://doi.org/10.1108/02686900710819634.

Hoitash, U., Hoitash, R. \& Bedard, J.C. (2009). Corporate governance and internal control over financial reporting: a comparison of regulatory regimes. The Accounting Review, 84(3), 839-867. https://doi.org/10.2308/accr.2009.84.3.839.

Jaffar, R., Jamaludin, S. \& Rahman, M. (2007). Determinant factors affecting quality of reporting in annual report of Malaysian companies. Malaysian Accounting Review, 6(2), 19-42. https://doi.org/10.1108/20421161211229808.

Jensen, MC. \& Meckling, WH. (1976). Theory of the firm: Managerial behavior, agency costs and ownership structure. Journal of Financial Economics, 3(4), 305-306. http://hupress.harvard.edu/catalog/JENTHF.html.

Jiang, H., Habib, A., Baiding, H. (2011). Ownership concentration, voluntary disclosures and information asymmetry in New Zealand. The British Accounting Review, 43(1), 39-53. https://doi.org/10.1016/j.bar.2010.10.005.

Kamolsakulchai, M. (2015). The impact of the audit committee effectiveness and audit quality on financial reporting quality of listed company in stocks exchange of Thailand. Review of Integrative Business \& Economics Research, 4(2), 328-341.

Kansal, M., Joshi, M. \& Batra, G.S. (2014). Determinants of Corporate Social Responsibility Disclosures: Evidence from India. Advances in Accounting, 30(1), 217-229. https://doi.org/10.1016/j.adiac.2014.03.009.

Khlif. H. \& Souissi. M. (2010). The determinants of corporate disclosure: a meta analyses. The International Journal of Accounting \& Information Management, 18(3), 198 - 219. https://doi.org/10.1108/18347641011068965.

Kiattikulwattana, P. (2014). Earnings management and voluntary disclosure of management's responsibility for the financial reports. Asian Review of Accounting, 22(3), 233-256, https://doi.org/10.1108/ARA-11-2013-0075. 
Lang, M., Lundholm, R. (2000). Voluntary disclosure during equity offerings: Reducing information asymmetry or hyping the stock? Contemporary Accounting Research, 174, 623-662. https://doi.org/10.1506/9N45-F0JX-AXVW-LBWJ.

Latridis, G. \& Alexakis, P. (2012). Evidence of voluntary accounting disclosures in the Athens Stock Market. Review of Accounting and Finance, 11(1), 73-92. http://dx.doi.org/10.1108/14757701211201830.

Lawrence, S.R., Botes, V., Collins, E. \& Roper, J. (2013). Does accounting construct the identity of firms as purely self-interested or as socially responsible? Meditari Accountancy Research, 21(2), 144-160. https://doi.org/10.1108/MEDAR-09-2012-0030.

Lee, H., Mande, V. \& Ortman, R. (2004). The effect of audit committee and board of director independence on auditor resignation. Auditing: A Journal of Practice and Theory, 23(2), 131-146. https://doi.org/10.2308/aud.2004.23.2.131.

Leventis, S. \& Weetman, P. (2004a). Impression management: dual language reprinting and voluntary disclosure. Accounting Forum, 28, 307 - 28. https://doi.org/10.1016/j.accfor.2004.07.004.

Lim S.J, White, G., Lee, A., Yuningsih, Y. (2017). A longitudinal study of voluntary disclosure quality in the annual reports of innovative firms. Accounting Research Journal, 30(1), 89-106, https://doi.org/10.1108/ARJ-08-2013-0056.

Lobo, J.L. \& Zhou, J. (2005a). To swear early or not to swear early? An empirical investigation of factors affecting CEOs' decisions. Journal of Accounting and Public Policy, 24(2), 153-160. https://doi.org/10.1016/j.jaccpubpol.2004.12.008.

Magness, V. (2006). Strategic posture, financial performance and environmental disclosure: An empirical test of legitimacy theory. Accounting, Auditing and Accountability Journal, 19(4), 540-563. http://dx.doi.org/10.1108/09513570610679128.

Mande, V. \& Son, M. (2015). How Do Auditor Fees Affect Accruals Quality? Additional Evidence. International Journal of Auditing, 19(3). https://doi.org/10.1111/ijau.12038.

Marston, C. \& Polei, A. (2004). Corporate reporting on the Internet by German companies. International Journal of Accounting Information System, 5(3), 285-311. https://doi.org/10.1016/j.accinf.2004.02.009.

Massumi, B. (1987). Introduction: Rhizome. A Thousand Plateaus: Capitalism and Schizophrenia. University of Minnesota Press, Minneapolis, MN.

Meyer, J.W., Scott, W.R. \& Deal, T.E. (1983). Institutional and technical sources of organizational structure: explaining the structure of educational organization. in Meyer, J.W. and Scott, W.R. (Eds), Organizational Environments: Ritual and Rationality, Sage, Beverly Hills, CA. pp. 45-67.

Mitchell, V.Z., Singh, H. \& Singh, I. (2008). Association between independent audit committee members' human-resource features and underpricing: the case of Singapore IPOs from 1997-2006. Journal of Human Resource Costing \& Accounting, 12(3), 179-212. https://doi.org/10.1108/14013380810919840.

Murray, A., Sinclair, D., Power, D., \& Rray, R. (2006). Do financial markets care about social and environmental disclosure? Further evidence and exploration from the UK. Accounting, Auditing \& Accountability Journal, 19(2), 228-255, https://doi.org/10.1108/09513570610656105.

Niléhn, P., \& Thoresson, A. (2014). Determinants of Voluntary Disclosures in Swedish Corporate Annual Reports (Master's Theses). Uppsala University.

Ojah, K. \& Mokoteli, T. (2012). Internet Financial Reporting, Infrastructures and Corporate Governance: an International Analysis. Review of Financial Economics, 2, 69-83. https://doi.org/10.1016/j.rdf.2012.04.001.

Orlowski, A. (2003). A Quantum Theory of Internet Value. The Register: Internet and Law, December.

Ousama, A.A., Fatima, A.-H. \& Hafiz-Majdi, A.R. (2012). Determinants of intellectual capital reporting: evidence from annual reports of Malaysian listed companies. Journal of Accounting in Emerging Economies, 2(2), 119-139. https://doi.org/10.1108/20421161211229808.

Owusu-Ansah, S. \& Yeoh, J. (2005). The effect of legislation on corporate disclosure practices. Abacus, A journal of Accounting, Finance and Business Studies, 41(1), 92-109. https://doi.org/10.1111/j.1467-6281.2005.00171. 
Oyar, M. (2013). The Impact of Switching Standards on Accounting Quality. Journal of Modern Accounting and Auditing, 9, 459-479.

Oyeler, P., Laswad, F. \& Fisher, R. (2003). Determinants of internet financial reporting by New Zealand listed companies. Journal of International Financial Management and Accounting, 14(1), 26-63. http://dx.doi.org/10.1111/1467-646X.00089.

Paton, W. (1962). Accounting Theory, Scholars Book Company. New York, NY.

Pirolli, P. \& Card, S. (1999). Information foraging. Psychological Review, 106(1), 643-675.

Posner, R.A. (1974). Theories of economic regulation. Bell Journal of Economics, 5(2), 335-358. https://doi.org/10.3386/w0041.

Rao, S. (2002). Application of human-computer interaction theories to information design on internet portals. unpublished master's thesis, Virginia Polytechnic Institution and State University, Blacksburg, VA.

Rezaee, Z. \& Tuo, L. (2017). Are the Quantity and Quality of Sustainability Disclosures Associated with the Innate and Discretionary Earnings Quality? Journal of Business Ethics, https://doi.org/10.1007/s10551-017-3546-y.

Ronald P.G. \& Dennis M.P. (2010). Market reactions to the first-time issuance of corporate sustainability reports: Evidence that quality matters. Sustainability Accounting, Management and Policy Journal, 1(1), 33-50, https://doi.org/10.1108/20408021011059214.

Salehi, M., Moradi, M. \& Paiydarmanesh, N. (2017). The effect of corporate governance and audit quality on disclosure quality: evidence from Tehran stock exchange. Periodica Politechnica Social and Management Sciences, 25(1), 32-48. https://doi.org/10.5296/ajfa.v6i2.6000.

Samkin, G. (2012). Changes in sustainability reporting by an African defense contractor: a longitudinal analysis . Meditari Accounting Research, 20(2), 134-166. DOI: 10.1108/10222521211277834.

Sankara, J., Dennis M. Patten, Deborah L. Lindberg. (2019). Mandated social disclosure: Evidence that investors perceive poor quality reporting as increasing social and political cost exposures. Sustainability Accounting, Management and Policy Journal, https://doi.org/10.1108/SAMPJ-05-2017-0046.

Shiri, MM., Salehi, M. \& Radbon, A. (2016). A Study of Impact of Ownership Structure and Disclosure Quality on Information Asymmetry in Iran. The Journal for Decision Makers, 41(1).

Solomon, J.F. \& Solomon, A. (2006). Private, Social ethical and environmental disclosure. Accounting Auditing \& Accountability Journal, 19(4), 564-591. http://dx.doi.org/10.1108/09513570610679137.

Spence, A.M. (1973). Job market signaling. The Quarterly Journal of Economics, 87(2), 355-379. http://links.jstor.org/sici?sici=0033-5533\%28197308\%2987\%3A3\%3C355\%3AJMS\%3E2.0.CO\%3B2-3.

Stanley, J.D. \& DeZoort, F.T. (2007). Audit firm tenure and financial restatements: an analysis of industry specialization and fee effects. Journal of Accounting and Public Policy, 26(2), 131-159. https://doi.org/10.1016/j.jaccpubpol.2007.02.003.

Stewart, J. \& Munro, L. (2007). The Impact of Audit Committee Existence and Audit Committee Meeting Frequency on the External Audit: Perceptions of Australian Auditors. International Journal of Auditing, 11(1), pp. 51-69. https://doi.org/10.1111/j.1099-1123.2007.00356.x.

Stolowy, H. \& Lebas, M. (2002). Corporate Financial Reporting: A Global Perspective. Thomson Learning, Boston.

Summerhays, K. \& De Villiers, C. (2012). Oil company annual report disclosure responses to the 2010 Gulf of Mexico oil spill. Journal of the Asia-Pacific Centre for Environmental Accountability, 18(2), 103-130. https://hdl.handle.net/10289/6730.

Suojanen, W. (1954). Accounting theory and the large corporation. Accounting Review, 29(3), 391-398.

Tslavotas, I. \& Dionysiou, D. (2011). Value relevance of IFRS mandatory disclosure requirements. Journal of Applied Accounting Research, 15(1). https://doi.org/10.1108/JAAR-03-2013-0021.

Vafees, N. (2005). Audit Committees, Boards, and the Quality of Reported Earnings. Contemporary Accounting Research, 22(4), 1093-1122. https://doi.org/10.1506/1QYN-2RFQ-FKYX-XP84. 
Wang, Q., Wong, T.J \& Xia, L. (2008). State ownership, the institutional environment, and auditor choice: evidence from China. Journal of Accounting and Economics, 46(1), 112-134. https://doi.org/10.1016/j.jacceco.2008.04.001.

Wang, Sh., Han, L. \& Gao, W. (2015). Mandatory and voluntary information disclosure and the effects on financial analysts: Evidence from China. Chinese Management Studies Journal, 9(3), 425-440. https://doi.org/10.1108/CMS-01-2015-0012.

Watson, A., Shrives, P. \& Maston, C. (2002). Voluntary disclosure of accounting ratios in the UK. British Accounting Review, 34(4), 289-313. http://dx.doi.org/10.1006/bare.2002.0213.

Xie, B., W. Davidson III, \& DaDalt, P. (2003). Earnings management and corporate governance: The roles of the board and the audit committee. Journal of Corporate Finance, 9(3), 295-316. https://doi.org/10.1016/S0929-1199(02)00006-8.

Yuniarti, R. (2011). Audit firms size, audit fee and audit quality. Journal of Global Management, 2(1), 84-97. 